\title{
Pemanfaatan Metode Jigsaw Untuk Meningkatkan Prestasi Belajar Menangani Administrasi Keuangan Bagi Kelas XI Administrasi Perkantoran 1 Di SMK Negeri 1 Kota Sorong Tahun 2017
}

\author{
Kistana \\ Email: kistana147@gmail.com
}

\begin{abstract}
This research aimed to determine The Increase in Learning Achievement Finance AdministrationHandle for XI Grade of the Office Administration 1 in SMKN 1 Sorong City Through the Using of Jigsaw Method. This type of reseach is a collaborative class between researcher and collaborator teacher. The reseach was conducted in two cycles, each cycle consisting of four components namely planning, action, observation and reflection. The data collection techniques used in this reseach are interviews, observations, documentations and tests. The data analysis is done in three stages that are: reduction, data presentation and draw conclusion. The results of this research showed that: (a) The Exploiting of Jigsaw Method can improve the learning achievement of students. The increase of learning achievement in handling financial administration can be seen through the listening aspect in the first cycle was $61 \%$ increased to 91 $\%$ in the second cycle. The participation in recording annotation in the first cycle was $55 \%$ increased to $79 \%$ in the second cycle. The participation in paying attention to learning in the first cycle was $58 \%$ increased to $88 \%$ in the second cycle. The participation in asking in the first cycle was $45 \%$ increased to $73 \%$ in the second cycle. The participation in answering questions in the first cycle was $52 \%$ increased to $82 \%$ in the second cycle. The participation in issuing opinion in the first cycle was $45 \%$ increased to $82 \%$ in the second cycle. The participation in respecting the opinion of friends in the first cycle was $55 \%$ increased to $76 \%$ in the second cycle. The participation in explaining back in the first cycle was $48 \%$ increased to $82 \%$ in the second cycle. (b) The Exploiting Jigsaw Method can improve the learning achievement of students. The average learning outcomes of students in the first cycle was 63,33 increased to 75,76 in the second cycle.

Keywords: Jigsaw Method, Learning Achievement of Finance Administration Handle, and SMKN 1 Sorong City.
\end{abstract}

\begin{abstract}
Abstrak: Penelitian ini bertujuan untuk mengetahui peningkatan Prestasi Belajar Menangani Administrasi Keuangan bagi siswaKelasXI Administrasi Perkantoran 1 diSMK Negeri 1 Kota Sorong melalui pemanfaatan Metode Jigsaw. Jenis penelitian ini adalah penelitian tindakan kelas (Classroom Action Research) yang dilakukan secara kolaboratif antara peneliti dengan guru kolaborator. Penelitian dilaksanakan dalam dua siklus, masing-masing siklus terdiri dari empat komponen yaitu perencanaan, tindakan, pengamatan dan refleksi. Teknik pengumpulan data yang digunakan dalam penelitian ini adalah wawancara, observasi, dokumentasi dan tes. Analisis data dilakukan dalam 3 tahap yaitu reduksi, penyajian data serta menarik kesimpulan. Hasil penelitian menunjukkan bahwa: (a) pemanfaatan Metode Jigsaw dapat meningkatkan partisipasi belajar siswa. Peningkatan Prestasi Belajar Menangani Administrasi Keuangan dapat dilihat melalui aspek mendengarkan penjelasan pada siklus I sebesar $61 \%$ meningkat menjadi sebesar $91 \%$ pada siklus II. Partisipasi dalam mencatat penjelasan siklus I sebesar $55 \%$ meningkat menjadi sebesar $79 \%$ pada siklus II. Partisipasi dalam memperhatikan pembelajaran siklus I sebesar 58\% meningkat menjadi sebesar $88 \%$ pada siklus II. Partisipasi dalam bertanya siklus I sebesar $45 \%$ meningkat menjadi sebesar $73 \%$ pada siklus II. Partisipasi dalam menjawab pertanyaan siklus I sebesar 52\% meningkat menjadi
\end{abstract}


sebesar $82 \%$ pada siklus II. Partisipasi dalam mengeluarkan pendapat siklus I sebesar 45\% meningkat menjadi sebesar $82 \%$ pada siklus II. Partisipasi dalam menghargai pendapat teman siklus I sebesar $55 \%$ meningkat menjadi sebesar $76 \%$ pada siklus II. Partisipasi dalam menjelaskan kembali siklus I sebesar $48 \%$ meningkat menjadi sebesar 82\% pada siklus II. (b) Pemanfaatan Metode Jigsaw dapat meningkatkan prestasi belajar siswa. Rata-rata hasil belajar siswa pada siklus I sebesar 63,33 meningkat menjadi 75,76 pada siklus II.

Kata kunci: Metode Jigsaw, PrestasiBelajarMenangani Administrasi Keuangan, SMK Negeri 1 Kota Sorong.

\section{Pendahuluan}

SMK Negeri 1 Sorong berdiri tahun 1971, saat ini mempunyai visi menjadi Sekolah Rujukan.Sehingga harapannya dalam kegiatan belajar mengajar idealnya suasana kelas lebih hidup, ada interaksi antara guru dan siswa. Selain itu siswa diharapkan aktif dan kreatif mengikuti pelajaran. Menurut Dokumen I Kurikulum SMK Negeri 1 Sorong kriteria ketuntasan minimal untuk mata pelajaran Administrasi Keuangan adalah 70.

Kondisi di atas tidak sesuai dengan harapan peneliti.Saat peneliti mengajar di kelas XI Administrasi Perkantoran 1dijumpai 75\% siswa tidak memahami materiAdministrasi Keuangan. Siswa saat kegiatan pembelajaran jika ditanya guru tidak mampu menjawab. Apalagi jika diminta bertanya. Separuh siswa tidak berani mengemukakan pendapat.

Dari permasalahan tersebut, peneliti merasa bahwa kemampuan menguasai materi pelajaranAdministrasi Keuanganperlu dipahami siswa. Hal ini di karenakan nilai rata-rata kelas belum mencapai KKM yang diharapkan. Selain itu saat ditanya guru siswa tidak mampu menjawab. Saat kegiatan belajar mengajar suasana kelas sangat monoton sehingga perlu dicari strategi pembelajaran yang merangsang siswa untuk aktif, kreatif, dan menyenangkan.

Berdasarkan uraian di atas maka penulis tertarik untuk melakukan penelitian dengan mengambil judul "Pemanfaatan Metode Jigsaw untuk Meningkatkan Prestasi Belajar Menangani Administrasi Keuangan bagi SiswaKelas XI Administrasi Perkantoran 1 di SMK Negeri 1 Kota Sorong Tahun 2017”.

\section{Metode Penelitian}

\subsection{Desain Penelitian}

Penelitian ini merupakan penelitian tindakan kelas (classroom action research), yaitu pencermatan terhadap kegiatan belajar berupa sebuah tindakan, yang sengaja dimunculkan dan terjadi dalam sebuah kelas secara bersama. Penelitian tindakan kelas ini terdiri atas rangkaian empat kegiatan yang dilakukan dalam siklus berulang. Empat 
kegiatan utama yang ada pada setiap siklus, yaitu : perencanaan (planning), tindakan (acting),observasi (observing),dan refleksi (reflecting). Berdasarkan langkah ini akan dapat diketahui perubahan yang terjadi dan dapat dilakukan tindakan sehingga mampu mencapai perubahan atau mengatasi masalah secara signifikan.

\subsection{Tempat dan Waktu Penelitian}

Penelitian dilaksanakan di SMK Negeri 1 Kota Sorong yang beralamat di Jalan Pendidikan Km. 8 Kota Sorong. Pemilihan SMK Negeri 1 Kota Sorong, karena belum dimanfaatkannya Metode Jigsaw untuk pembelajaran pada mata pelajaran Administrasi Keuangan.Penelitian ini dilaksanakan pada tanggal 23 Januari 2017 sampai dengan tanggal 3April2017.

\subsection{Subjek dan Objek Penelitian}

Subjek dalam penelitian ini adalah siswa kelas SMK Negeri 1 Kota Sorong. Sedangkan yang menjadi objek penelitian adalah Prestasi Belajar Menangani Administrasi Keuangan dengan pemanfaatan Metode Jigsaw. Peneliti memilih siswa KelasXI Administrasi Perkantoran 1 karena belum mencapai KKM untuk mata pelajaran Administrasi Keuangan khususnya pada Prestasi Belajar Menangani Administrasi Keuangan.

\subsection{Teknik Pengumpulan Data}

Pada pengamatan ini menggunakan observasi partisipan, yaitu observasi yang dilakukan oleh pengamat, tetapi dalam pada itu pengamat memasuki dan mengikuti kelompok yang sedang diamati.Observasi ditujukan kepada subyek yang akan diteliti yaitu siswa. Untuk mengamati secara langsung kegiatan pembelajaran mata pelajaran Administrasi Keuangan.

Wawancara dilakukan pada siswa dengan menggunakan pedoman wawancara yang berisi tentang petunjuk garis besar isi wawancara.

Dalam penelitian ini tes digunakan untuk mengumpulkan data tentang hasil belajar siswa dalam upaya peningkatan prestasi siswa.

\subsection{Teknik Analisis Data}

Data observasi yang telah diperoleh, dihitung, kemudian dipersentasekan. Sehingga dapat diketahui seberapa besar peningkatan partisipasi siswa dalam pembelajaran. Untuk mengetahui peningkatan prestasi belajar siswa, peneliti menggunakan Kriteria Ketuntasan Minimal (KKM) pada mata pelajaran Administrasi Keuangan,yaitu 70. 
Partisipasi aktif siswa dikatakan berhasil jika partisipasi belajar 75\% siswasecara aktif berperan selama proses pembelajaran berlangsung, dengan melihat dari aspek-aspek yang diamati dalam lembar observasi selama penelitian berlangsung. Prestasi belajar siswa dikatakan berhasil jika prestasi belajar 75\%siswa pada akhir siklus telah mencapai 70. Hal tersebut sesuai dengan Kriteria Ketuntasan Minimal (KKM) yang telah diterapkan oleh SMK Negeri 1 Kota Sorong untuk mata pelajaran Administrasi Keuangan.

\section{Hasil Penelitian Dan Pembahasan}

\subsection{Hasil Penelitian}

\subsubsection{Hasil Observasi}

Selama kegiatan belajar mengajar berlangsung observer melakukan pengamatan secara langsung mengenai partisipasi yang ditunjukkan oleh siswa dalam mata pelajaran Administrasi Keuangan. Dalam penelitian ini, unsur-unsur yang termasuk dalam partisipasi siswa atau keaktifan siswa meliputi mendengarkan penjelasan guru, mencatat penjelasan guru, memperhatikan pembelajaran, bertanya, menjawab pertanyaan, mengeluarkan pendapat, menghargai pendapat teman, refleksi/menjelaskan kembali.

Dari pengamatan pada siklus I dapat diketahui bahwa siswa yang mendengarkan penjelasan sebanyak $61 \%$, mencatat penjelasan $55 \%$, memperhatikan pembelajaran $58 \%$, bertanya $45 \%$, menjawab pertanyaan $52 \%$, mengeluarkan pendapat $45 \%$, menghargai pendapat teman 55\%, mampu menjelaskan kembali $48 \%$.

Pada siklus II ini tingkat partisipasi aktif siswa sudah mulai menunjukkan adanya peningkatan yang relatif stabil dan hampir semua siswa sudah memperhatikan, berpartisipasi dan mengikuti proses pembelajaran. Semua ini dapat dilihat dengan adanya peningkatan dari hampir semua aspek yang diamati yaitu siswa yangmendengarkan penjelasan $91 \%$, mencatat penjelasan bertanya $79 \%$, memperhatikan pembelajaran $88 \%$, bertanya $73 \%$, menjawab pertanyaan $82 \%$, mengeluarkan pendapat $82 \%$, menghargai pendapat teman $76 \%$, mampu menjelaskan kembali $82 \%$.

\subsubsection{Hasil Tes}

Berdasarkan rata-rata siswa pada post test 1 dapat diketahui sebesar 63,33. Hal ini menunjukkan bahwa terjadi peningkatan hasil belajar siswa setelah menggunakan Metode Jigsaw pada mata pelajaran Administrasi Keuangan. Namun berdasarkan nilai siswa pada siklus I di atas, kriteria keberhasilan belum tercapai, karena masih terdapat 16 
siswa belum mencapai KKM, sehingga perlu dilanjutkan dengan siklus berikutnya yaitu siklus II.

Hasil Tes, berdasarkan rata-rata hasil belajar antara tes pada siklus I dan siklus II yang diketahui bahwa pada tes II $(75,76)$ mempunyai rata-rata lebih tinggi dibandingkan dengan rata-rata pada tes yang dilakukan di siklus I $(63,33)$. Hal ini menunjukkan adanya terjadi peningkatan pada hasil belajar pada siklus II dalam mata pelajaran Administrasi Keuangan. Berdasarkan rata-rata pada siklus II di atas, kriteria keberhasilan sudah tercapai karena lebih dari $75 \%$ siswa telah mencapai KKM bahkan $81,82 \%$ siswa mencapai KKM, hal ini menunjukkan adanya pencapaian tingkat keberhasilan sesuai dengan kriteria keberhasilan yang telah ditetapkan.

\subsection{Pembahasan}

Dalam penelitian ini, pembahasan lebih difokuskan pada Pelaksanaan Metode Jigsaw untuk meningkatkan partisipasi aktif dan prestasi belajar siswa dilakukan dalam dua siklus dan dilaksanakan dalam empat pertemuan di kelas. Penerapan Metode Jigsaw pada siklus I dilakukan dalam dua kali pertemuan, tetapi di dalam pelaksanaannya belum tercipta peningkatan partisipasi aktif dan prestasi belajar siswa secara maksimal, maka peneliti sepakat untuk melanjutkan pada siklus berikutnya yaitu siklus II. Siklus demi siklus terbentuk untuk memberikan perbaikan dan perbandingan di dalam pembelajaran agar partisipasi aktif dan prestasi belajar lebih meningkat sesuai dengan apa yang diharapkan peneliti.

Hasil penelitian tindakan siklus I dan II dengan penggunaan Metode Jigsaw menunjukkan adanya peningkatan terhadap aktivitas belajar siswa. Peningkatan terjadi pada observasi siklus II di mana dalam observasi ini yang diamati adalah partisipasi aktif siswa. Dari hasil observasi diperoleh data aktivitas siswa sebagai berikut: pada indikator mendengarkan penjelasan persentase siswa dalam kelas pada siklus I sebesar $61 \%$ dan pada siklus II meningkat menjadi91\%, indikator mencatat penjelasan persentase siswa dalam kelas pada siklus I sebesar 55\% dan pada siklus II sebesar 79,indikator memperhatikan pembelajaran persentase siswa dalam kelas pada siklus I sebesar 58\% dan pada siklus II sebesar 88, indikator bertanya persentasae siswa dalam kelas pada siklus I $45 \%$ dan pada siklus II sebesar 73, indikator menjawab pertanyaan persentase siswa dalam kelas pada siklus I sebesar 52\% dan pada siklus II sebesar 82, Indikator mengeluarkan pendapat persentase siswa dalam kelas pada siklus I sebesar $45 \%$ dan pada siklus II sebesar $82 \%$, indikator menghargai pendapat teman persentase siswa dalam kelas pada siklus I sebesar $55 \%$ dan pada siklus II sebesar $76 \%$, dan pada indikator 
refleksi/mampu menjelaskan kembali persentase siswa dalam kelas pada siklus I sebesar $48 \%$ dan pada siklus II sebesar $82 \%$.

Berdasarkan pemaparan prestasi belajar di atas dapat diberikan penjelasan bahwa telah terjadi peningkatan prestasi belajar siswa dari siklus I mencapai rata-rata 63,33 naik menjadi rata-rata 75,76 pada tahap siklus II, peningkatan nilai tertinggi yang diperoleh siswa dari siklus I sebesar 70, sedangkan pada siklus II meningkat menjadi sebesar 90, peningkatan nilai terendah yang diperoleh siswa dari siklus I sebesar 50 sedangkan pada siklus II meningkat menjadi sebesar 60, danterdapat peningkatan jumlah tuntas individu atau siswa yang mencapai Kriteria Ketuntasan Minimal (KKM) dari siklus I sebesar 17 siswa sedangkan pada siklus II meningkat menjadi sebesar 27siswa, serta terdapat peningkatan persentase ketuntasan individu siklus I terdapat 51,52 \% siswa sedangkan pada siklus II terdapat 81,82 \% siswa telah mencapai KKM.

\section{Simpulan Dan Saran}

\subsection{Kesimpulan}

Berdasarkan hasil analisis data dan pembahasan yang telah peneliti lakukan, aktivitas belajar siswa Kelas XI Administrasi Perkantoran 1 di SMK Negeri 1 Kota Sorong untuk mata pelajaran Administrasi Keuangan, dapat ditarik kesimpulan sebagai berikut:

1. Penerapan pembelajaran dengan menggunakan Metode Jigsaw dapatmeningkatkan Prestasi Belajar Menangani Administrasi Keuangan padamata pelajaran Administrasi Keuangan siswa Kelas XI Administrasi Perkantoran 1 dilihat dari adanya peningkatan persentase.

2. Peningkatannya dapat dilihat dari hasil observasi pada siklus I dan siklus II. Pada Aspek mendengarkan penjelasan siklus I sebesar $61 \%$ dan siklus II sebesar $91 \%$. Aspek mencatat penjelasan siklus I sebesar 55\% dan siklus II sebesar 79\%. Aspek memperhatikan pembelajaran siklus I sebesar $58 \%$ dan siklus II sebesar 88\%. Aspek bertanya siklus I sebesar $45 \%$ dan pada siklus II sebesar 73\%. Aspek menjawab pertanyaan siklus I sebesar $52 \%$ dan siklus II sebesar $82 \%$. Aspek mengeluarkan pendapat siklus I sebesar $45 \%$ dan pada siklus II sebesar $82 \%$. Aspek menghargai pendapat teman siklus I sebesar 55\% dan pada siklus II sebesar $76 \%$. Aspek mampu menjelaskan kembali siklus I sebesar $48 \%$ dan pada siklus II sebesar $82 \%$. Hal ini menunjukkan bahwa terjadi peningkatan terhadap partisipasi aktif siswa pada mata pelajaran Administrasi Keuangan. 
3. Metode Jigsaw juga dapat meningkatkan hasil belajar pada mata pelajaran Administrasi Keuangandi kelas. Peningkatan hasil belajar ini dapat dilihat dari adanya perubahan nilai rata-rata yang diperoleh siswa pada setiap akhir siklus. Nilai rata-rata yang diperoleh siswa pada siklus I sebesar 63,33 dan siklus II sebesar 75,76. Hal tersebut membuktikan bahwa dengan menggunakan Metode Jigsaw dapat meningkatkan prestasi belajar siswa.

\subsection{Saran}

Berdasarkan hasil penelitian dan pembahasan maupun kesimpulan di atas, dapat diajukan beberapa saran:

1. Guru perlu mengupayakan partisipasi belajar siswa dengan cara melanjutkan pembuatan Metode Jigsaw pada mata pelajaran Administrasi Keuangan untuk pertemuan-pertemuan selanjutnya agar siswa tertarik dalam memahami materi yang diberikan dalam proses pembelajaran sehingga partisipasi siswa dapat bertahan bahkan meningkat.

2. Guru perlu mengupayakan prestasi belajar siswa dengan cara melanjutkan pembuatan Metode Jigsaw pada mata pelajaran Administrasi Keuangan untuk pertemuanpertemuan selanjutnya agar siswa tertarik dalam memahami materi yang diberikan dalam proses pembelajaran sehingga prestasi siswa dapat bertahan bahkan meningkat.

\section{Daftar Pustaka}

Mulyasa. (2004). Menjadi Guru professional. Bandung: PT Remaja Rosdakarya.

Nana Sudjana. (2006). Penilaian Hasil Proses Belajar Mengajar. Bandung: PT Remaja Rosdakarya.

Ridwan. (2009). Skala Pengukuran Variabel-Variabel Penelitian. Bandung: Alfabeta.

Rochiati Wiriaatmadja. (2009). Metode Penelitian Tindakan Kelas. Bandung: PT Remaja Rosdakarya.

Slameto. (2010). Belajar dan Faktor-Faktor yang Mempengaruhi. Jakarta: Rineka Cipta. Sugihartono. (2007). Psikologi Pendidikan. Yogyakarta: UNY Press.

Suharsimi Arikunto. (2009). Dasar-dasar Evaluasi Pendidikan (Edisi Revisi, cetakan 7). Jakarta: Bumi Aksara

Suharsimi Arikunto, dkk. ( 2016). Penelitian Tindakan Kelas.Jakarta : Bumi Aksara. Sumadi Suryabrata. (2006). Psikologi Pendidikan. Jakarta:PTRaja Grafindo Persada. 